\title{
WARNA SEBAGAI LOOK DAN MOOD PADA VIDEOGRAFI FILM TELEVISI "PANCER"
}

\author{
Mandella Majid Pracihara \\ mamenmajid@gmail.com
}

\begin{abstract}
Abstrak
Manfaat warna dalam film mampu menciptakan look (nuansa) dan $\operatorname{mood}$ (suasana) serta memberikan bentuk tontonan baru terhadap masyarakat. Pancer dalam bahasa Jawa mempunyai arti jiwa, yang mana jiwa adalah unsur kelima pembentuk manusia. Dalam filosofi Jawa manusia terlahir dari 5 unsur yaitu "Kakang Kawah, Adhi Ari-Ari, Getih, Puser, Kang Limo Pancer". Pancer yang menjadi unsur terakhir inilah yang kemudian mampu menjadi jiwa dan terlahir sebagai manusia. Karya ini menitikberatkan pada teknis warnanya yang tidak konvensional untuk memunculkan pesan utama pada setiap proses hidup yang dialami manusia yaitu ingatan, perasaan, pikiran, dan kesadaran yang terjadi sepanjang hidup manusia Jawa. Film ini mencoba menjadi alternatif baru sebagai tontonan yang mengutamakan warna dan unsur visual sebagai pembawa pesan pada setiap adegannya. Warna yang digunakan dalam film merupakan warna dengan makna tertentu yang mampu menjelaskan filosofi Pancer. Warna tersebut mengambil dari struktur pohon kelapa gading yaitu : merah, kuning, putih, dan hitam. Kelapa gading dalam Jawa mempunyai filosofi semua bagian dari pohon kelapa mempunyai manfaat bagi kehidupan. Dalam teknis videografi warna dapat diciptakan melalui pencahayaan, artistik, properti dan kostum (tata busana).
\end{abstract}

Kata kunci : film televisi, Pancer, warna, videografi

\begin{abstract}
Color in the film is able to create the look and mood as well as giving a new shape to the public spectacle. Pancer in the Java language has meaning soul, which is the fifth element forming the soul of human. In Javanese philosophy humans are born of five elements, namely "Kakang Kawah, Adhi Ari-Ari, Getih, Puser, Kang Limo Pancer". Pancer who became the last element is then capable of being a soul and a human. This work focuses on the technical unconventional color to bring up the main message at every process of life that people experience are memories, feelings, thoughts, and consciousness that occurs throughout the life of Java man. This film tries to be a new alternative as a spectacle in which the color and visual elements as a messenger in every scene. Color used in the film is a color with a specific meaning that is able to explain the philosophy Pancer. The color take from the tree structure that ivory palm; red, yellow, white, and black. Kelapa Gading in Java has a philosophy all parts of the coconut tree has benefits for life. In technical videography colors can be created through lighting, artistic, props and costumes (fashion).
\end{abstract}

Keywords : film television, Pancer, color, videography

\section{Pendahuluan}

Salah satu elemen visual yang terpenting dan menarik perhatian adalah warna. Warna pada visual film menjadi faktor penting untuk dijadikan sebuah analisa baik secara unsur 
estetika, simbol, filosofis maupun secara teknis. Warna visual yang dihadirkan pada setiap adegan merupakan sebuah representasi dari unsur-unsur metafisika pembentuk manusia. Selain mengandung filosofi Jawa yang menarik, terdapat satu tantangan dari segi teknis pembuatan film, yaitu menampilkan warna yang mereprentasikan unsur dari diri manusia melalui media videografi.

Unsur manusia tersebut divisualkan melalui warna-warna yang sesuai dengan pemaknaan yang dibutuhkan. Warna yang dibangun dari sudut pandang teknis kamera dan pencahayaan dalam film televisi Pancer, menciptakan look dan mood untuk memberikan penekanan dramatisasi emosi pada setiap adegan.

Ide penciptaan berdasarkan fenomena masyarakat Jawa dalam diri manusia memliki saudara yang menyatu dalam diri dan memberikan pengaruh besar dalam kehidupan manusia. Masyarakat jawa biasa menyebutnya "Kakang kawah, adhi ari-ari, getih, puser kadang ku papat, kang limo Pancer”. Filosofi Jawa ini memiliki simbol unsur yaitu air, api, tanah, angin, dan manusia itu sendiri atau lebih di kenal dengan "Sedulur papat limo Pancer". Lima unsur ini secara mendasar telah membentuk karakter manusia dan saling berkaitan. Masing-masing unsur ditandai oleh warna dan memiliki pemaknaan disetiap unsur tersebut.

Unsur air mewakili kesadaran manusia, ditandai dengan warna putih. Unsur api mewakili perasaan manusia, ditandai dengan warna merah. Unsur angin mewakili pikiran manusia, ditandai dengan warna kuning. Unsur tanah mewakili ingatan manusia, ditandai dengan warna hitam. Unsur ke lima yaitu diri sendiri atau jiwa manusia yang disebut Pancer. Setiap kelahiran manusia, kelima unsur ini sudah ada pada diri manusia. Keterkaitan unsur tersebut menjadi pencapaian terakhir manusia yaitu keseimbangan dalam hidup. Penciptaan karya ini terbilang baru karena memadukan unsur warna sebagai pembangun adegan dengan latar belakang cerita mitos yang terjadi di masyarakat Jawa.

Karya sebelumnya yang pernah ada yaitu film "Hero" garapan sutradara Zhang Zimao, menggunakan warna untuk menghidupkan setiap karakter tokoh dalam film. Misalnya warna merah untuk adegan penuh emosi dan menunjukkan kemarahan tokoh. Warna merah tersebut membalut setiap unsur visual dalam setiap bingkai seperti artistik, kostum, properti, dan juga pencahayaan. Warna biru untuk menunjukkan dinginnya perang yang terjadi antarbangsa yang memiliki latar belakang budaya dan keyakinan yang berbeda. (sumber film HERO).

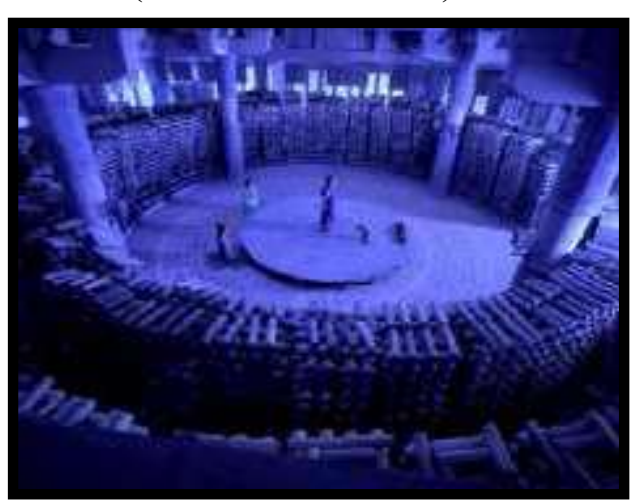

Screen capture 1: Referensi videografi pada warna biru

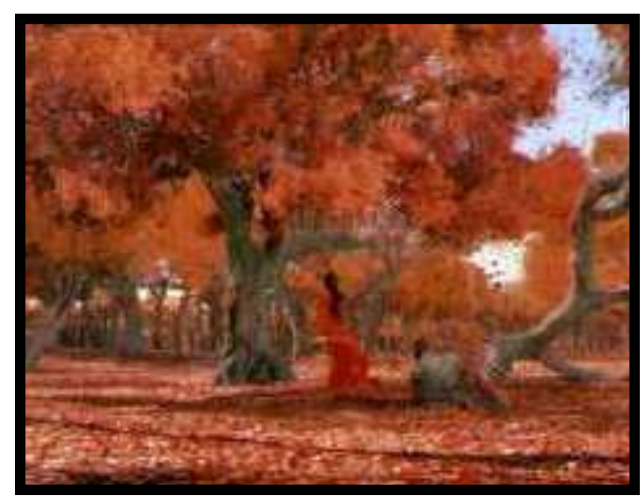

Screen capture $2:$ Referensi artistik dan pencahayaan 
Kasus lain seperti pada film "The Color Purple" garapan sutradara Steven Spielberg, film ini menceritakan tentang kehidupan kulit hitam di Amerika pada tahun 1900. "The Color Purple" atau warna ungu adalah simbol dari tokoh utama yang mengalami penyiksaan dan pemerkosaan dibawah umur pada saat dia menjadi seorang buruh kulit hitam. Perjalanan kehidupan seorang tokoh dalam film ini digambarkan seperti bunga lavender berwarna ungu yang mekar di ladang luas. (sumber film "The Color Purple")

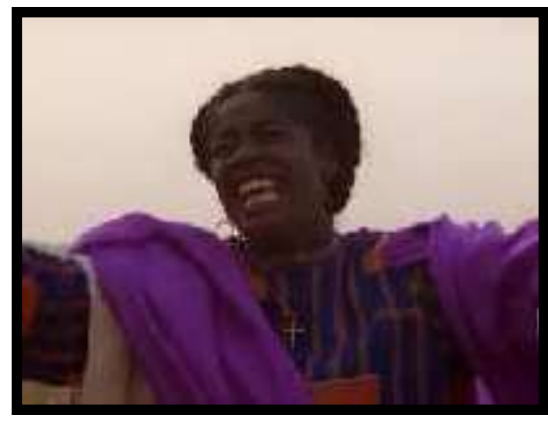

Screen capture 3 :

Referensi kostum dengan warna ungu

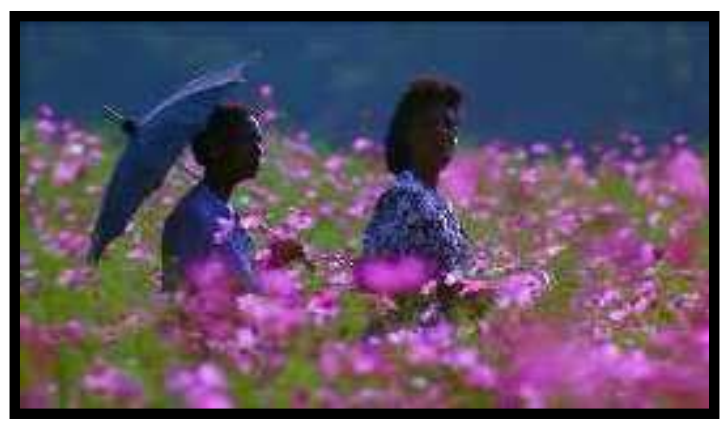

Screen capture 4 :

Referensi dimensi pada artistik

Pancer menggunakan studi kasus yang ada dalam film "Hero" dan "The Color

Purple", namun pengembangannya bukan hanya pada psikologis warnanya, namun warna dalam film ini juga merupakan pengembangan dari makna filosofi yang dihasilkan oleh Pancer yaitu merah, putih, hitam, dan kuning. Warna-warna tersebut diolah dan kemudian dimasukkan ke dalam setiap adegan sebagai simbol proses kehidupan yang berhubungan dengan ingatan, perasaan, kesadaran dan pikiran. Kakang kawah simbolnya adalah air yang diwakili dengan warna putih. Dalam segmen ini yang ingin disampaikan adalah hal-hal yang berkaitan dengan kesadaran. Adi ari-ari adalah tanah yang diwakili oleh warna hitam, segmen ini ingin menyampaikan tentang ingatan manusia. Getih yang berarti darah diwakilkan oleh warna merah, pesannya adalah tentang perasaan. Puser atau pusar diwakilkan oleh warna kuning yang berarti pikiran.

Tujuan pewarnaan visual dalam film ini secara simbolis untuk menyampaikan pesan tentang proses kehidupan manusia yang dibentuk dari ingatan, pikiran, perasaan dan kesadaran. Penyampaian pesan melalui bahasa gambar dalam film televisi menjadi aspek utama yang harus diciptakan melalui bentuk videografi dalam film televisi tersebut. Penggunaan pencahayaan, dekorasi artistik, properti dan kostum (tata busana) adalah aspek videografi untuk dapat membicarakan pesan secara informatif dan simbolis. Aspek videografi tersebut menambahkan nilai estetis dalam film televisi dan memberikan alternatif tontonan bagi masyarakat sehingga masyarakat saat ini dapat memahami filosofi Jawa. 


\section{Konsep Karya Estetis}

Warna dari sari buah kelapa yang diolah menjadi gula aren memiliki warna merah yang melambangkan unsur api menjadi visual warna untuk menyampaikan perasaan dari tokoh utama.

Warna kuning dari kulit buah kelapa gading yang melambangkan unsur angin menjadi dasar visualisasi warna untuk menyampaikan pikiran dari tokoh utama. Warna putih diperoleh dari isi buah kelapa yang berwarna putih mewakili lambang dari unsur air untuk mewujudkan kesadaran dari tokoh utama. Warna hitam diperoleh dari warna tanah yang melambangkan unsur tanah untuk mewujudkan ingatan dari tokoh utama. Warna juga mendukung dari segi naratif pada film televisi Pancer. Segi naratif yang dimaksudkan adalah informasi tentang warna mewakili keadaan psikologis dari tokoh dalam suatu rangkaian peristiwa yang berhubungan satu sama lain dan terikat oleh logika sebab-akibat (kausalitas) yang terjadi dalam suatu ruang dan waktu.

Warna dari setiap dekorasi artistik, disesuaikan dengan konsep yang menggunakan warna dari pohon kelapa. Dekorasi artistik yang memiliki karakter warna akan mewakilkan dan menggambarkan dari setiap kondisi yang dialami oleh Ratri (tokoh utama). Misalnya dengan warna merah yang mewakilkan dari perasaan sang tokoh, dekorasi artistik yang digunakan akan menyesuaikan dengan warna merah. Didukung oleh pemilihan properti yang sesuai dengan warna yang digunakan. Setiap salah satu warna yang digunakan pada dekorasi artistik film televisi Pancer memiliki tingkatan spektrum warna. Tingkatan warna ini akan membentuk dimensi kedalaman ruang dan nuansa dari setiap dekorasi artistik yang dimunculkan.

Konsep pencahayaan dalam film televisi ini menciptakan komposisi warna pada gambar. Detil objek yang terkena cahaya menciptakan dramatisasi adegan untuk membawa penonton dapat memahami pesan dari bahasa visual tersebut. Kostum akan disesuaikan juga dengan konsep waktu yang menunjukkan masa kini yang sesuai dengan unsur warna hitam, merah, kuning, dan putih. Kostum juga akan disesuaikan dengan kondisi sosiologis serta fisiologis dan psikologis dari setiap tokoh.

\section{Konsep Teknis Kamera}

Untuk memenuhi kebutuhan secara teknis videografi pada film televisi Pancer menggunakan kamera Canon DSLR. Kamera DSLR dengan kelas profesional ini memiliki ketajaman gambar yang sangat bagus, bahkan resolusi pada kamera ini bisa sampai full $H D$ 1920p, kualitasnya lebih baik dari pada resolusi televisi swasta Indonesia yang memiliki resolusi 1080p, dengan harapan kualitas gambar pada karya ini sangat baik, tetapi tidak menutup kemungkinan resolusi akan disamakan dengan televisi pada umumnya. Dari segi teknis untuk menciptakan warna kamera ini memiliki fasilitas yang disebut manual Kelvin.

Warna merah pada karya ini akan menggunakan ukuran suhu warna pada kisaran $800^{\circ} \mathrm{K}$ pada kamera. Warna kuning tidak memiliki perbedaan suhu warna yang jauh dengan warna merah, untuk menciptakan warna kuning akan menggunakan $2800^{\circ} \mathrm{K}$. Warna putih pada karya ini akan menggunakan suhu warna pada kisaran $4900^{\circ} \mathrm{K}$. Warna 
hitam akan menggunakan suhu warna pada kisaran $5100^{\circ} \mathrm{K}$. Pencapaian warna pada kamera juga menggunakan filter konversi warna pada lensa kamera. Filter konversi warna berfungsi untuk membantu membentuk sebuah warna dan juga untuk memunculkan warna.

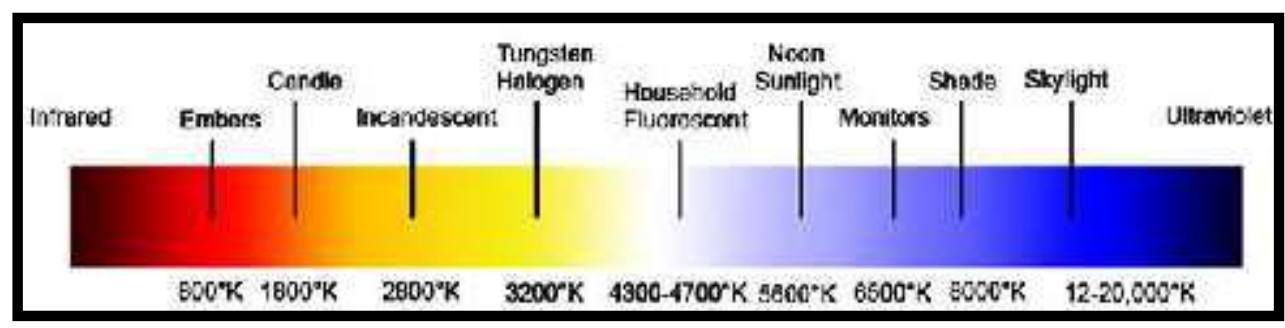

Gambar 1 : Diagram color temperature

Karya ini menggunakan filter berjenis enhancing, karena fiter ini akan mengikat suatu warna dan akan memunculkan warna-warna yang ditangkap oleh kamera. Filter enhancing akan memotong cahaya yang masuk ke dalam kamera sebesar 2 stop. Maka intensitas pencahayaan akan membutuhkan jenis lighting yang memiliki intensitas yang besar. Selain itu, pada karya ini juga menggunakan filter berjenis polarizer. Filter ini akan banyak menyerap cahaya. Tetapi filter ini tidak mengurangi intensitas cahaya yang masuk kedalam kamera. Tambahan filter untuk membentuk warna merah akan digunakan filter berjenis antique suade.

\section{Konsep Teknis Pencahayaan}

Penataan cahaya pada karya ini menggunakan dua kualitas cahaya high key dan low key. Kualitas cahaya low key akan mudah menggambarkan pesan yang disampaikan kepada penonton. Warna hitam pada film televisi ini menggunakan kualitas cahaya low key akan membuat bayangan tegas untuk memberikan penekanan kepada tokoh. Suasana dan nuansa yang dibangun dengan menggunakan kualitas cahaya low key pada karya ini terdapat pada adegan saat Ratri mengingat masa lalunya.

Suhu warna yang digunakan untuk menciptakan warna hitam menggunakan $5100^{\circ} \mathrm{K}$. Karakter cahaya digunakan adalah daylight dengan hanya menambahkan filter diffusion. Konsep teknis penataan cahaya dengan menggunakan high key digunakan pada adegan di luar ruangan dan adegan yang menggunakan konsep warna putih.

Tujuan dari konsep cahaya ini adalah untuk memberikan waktu nuansa yang cerah dan apabila digabungkan dengan konsep warna putih konsep tata cahaya ini akan menyampaikan pesan kesadaran pada tokoh utama.

Untuk menciptakan warna putih, suhu warna yang digunakan berkisar $4900^{\circ} \mathrm{K}$. Suhu ini berada di titik seimbang antara karakter cahaya daylight dan tungsten. Secara warna ini akan dibentuk dengan kualitas cahaya high key lighting atau soft light. Untuk membentuk suhu warna dari sumber cahaya, sumber cahaya akan ditambahkan filter gel Color Temperature Orange (CTO) $1 / 2$ untuk mengurangi suhu warna yang dikeluarkan agar tidak terlalu nampak terlalu biru. Dengan meminimalisir bayangan yang akan 
terkena sumber cahaya, sumber cahaya juga akan ditambahkan diffusion filter 216 untuk mengurangi intensitas cahaya dan menyebarkan cahaya yang jatuh kepada objek.

Warna kuning diciptakan melalui jenis dan karakter pencahayaan tungsten memiliki suhu warna $2800^{\circ} \mathrm{K}$. Penggunaan jenis filter CTO untuk memunculkan warna kuning dan untuk memberikan kepekatan warna kuning. Warna merah merupakan susunan warna yang tertinggi pada spectrum warna menurut ukuran nanometer. Untuk menciptakan warna merah menggunakan lampu berjenis daylight kemudian diberikan filter gel berjenis embers untuk mengkonversi warna tersebut. Warna merah yang sudah dikonversi akan berada pada suhu warna $800^{\circ} \mathrm{K}$.

\section{Tahapan Perwujudan Karya}

Tahapan proses perwujudan film televisi Pancer pada umumnya sama dengan melalui tiga tahapan yaitu pra produksi, produksi dan pasca produksi.

\section{Pra Produksi}

Penulisan skenario pada karya ini disesuaikan dengan konsep warna yang akan berpengaruh ke dalam struktur cerita. Penyusunan struktur ditentukan pembuatan sinopsis untuk mendasari jalan ceritanya. Pembuatan sinopsis akan menentukan pemilihan plot dan sub plot, penokohan, hambatan tokoh dan cara penyelesaiannya.

Pada proses pra produksi dilakukan perencanaan dekorasi artistik, pemilihan kostum dan penyesuaian teknis pencahayaan. Perencanaan dekorasi artistik disesuaikan dengan lokasi pengambilan gambar misalnya warna putih pada dekorasti artistik yang berlokasi di rumah sakit. Perencanaan ini digambarkan melalui storyboard untuk menjelaskan pesan warna putih.

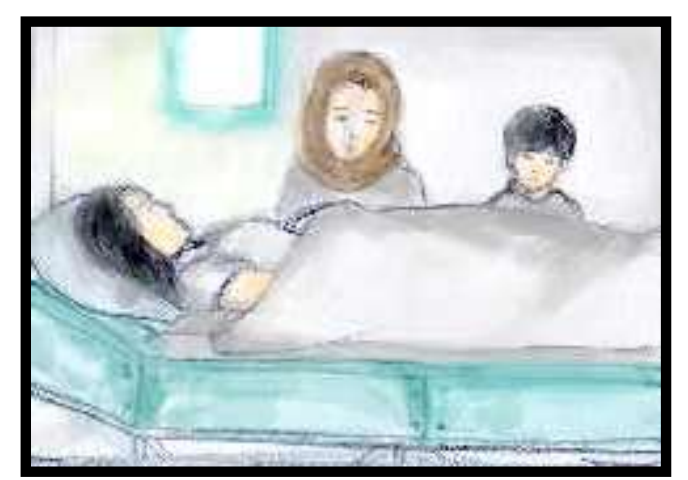

Gambar 2 : storyboard perencanaan pengambilan gambar warna putih. 


\section{Produksi}

Sebagai awal dari proses produksi pengambilan gambar direncanakan menyelesaikan delapan adegan dengan dua lokasi berbeda yaitu tujuh adegan di dalam ruangan dan satu adegan di luar ruangan. Jadwal pengambilan gambar disesuaikan dengan dekorasi warna dari dekorasi artistik yang telah dibangun untuk memenuhi kebutuhan visualnya. Dekorasi artistik mempersiapkan tempat di mana sudah disesuaikan dengan kebutuhan warna yang akan diambil.

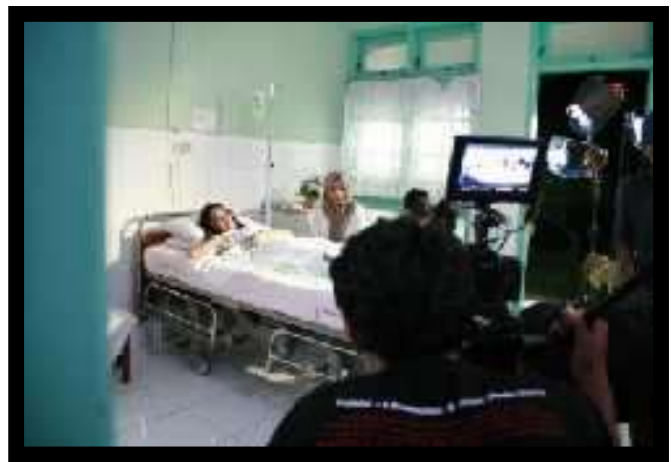

Gambar 3 :

Proses produksi pada lokasi di dalam ruangan dengan menggunakan warna putih sebagai konsep visualnya

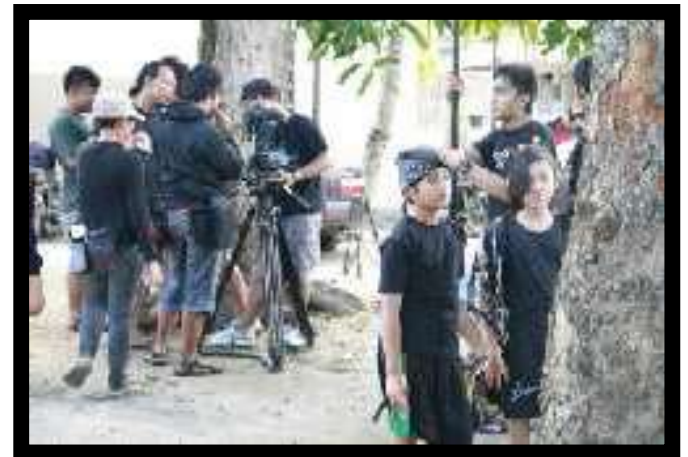

Gambar 4 :

Proses produksi pada lokasi di luar ruangan dengan menggunakan warna hitam sebagai konsep visualnya

\section{Pasca Produksi}

Tahap penyusunan hasil materi pengambilan gambar yang berupa shot-shot dan kemudian disusun untuk membangun cerita sehingga pesan yang terkandung dalam film dapat tersampaikan. Pada proses pasca produksi tidak melaukan proses pewarnaan terhadap hasil dari pengambilan gambar yang sudah dilakukan.

\section{Pembahasan Hasil Karya}

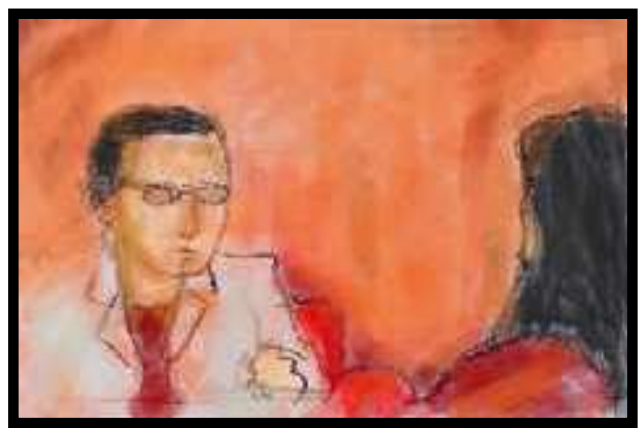

Gambar 5 :

Gambar storyboard perencanaan warna merah dan bentuk pengambilan gambar

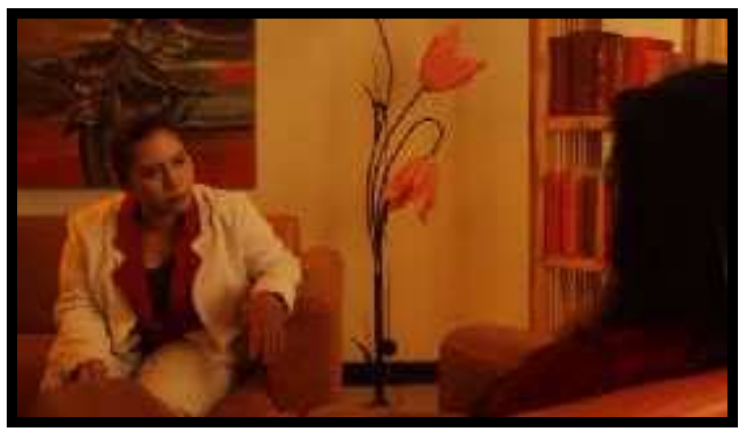

Gambar 6 :

Hasil proses penciptaan warna merah yang disesuaikan dengan perencanaan 
Warna merah yang diciptakan dengan menggabungkan antara dekorasi artistik, pencahayaan, kostum dan properti. Warna merah pada filosofi pohon kelapa gading diperoleh dari warna merah gula aren. Sehingga warna merah bukan warna merah yang murni merah, melainkan sedikit berwarna merah kecoklatan. Pada adegan ini warna merah diciptakan untuk menyampaikan pesan secara simbolis terhadap perasaan yang sedang dialami sang tokoh yang sedang mengunjungi seorang dokter psikolog.

Pada dekorasi nampak dominan warna merah untuk menciptakan nuansa merah dengan menempatkan properti dan asesoris yang juga berwarna merah. Pada pemilihan kostum yang digunakan oleh tokoh utama juga menggunakan busana yang berwarna merah tua. Identitas seorang tokoh dokter tetap mengenakan jas putih seperti layaknya dokter hanya saja dibagian dalam jas dikenakan kemeja berwarna merah.

Untuk mendukung nuansa yang diciptakan dan untuk menambah tingkatan dramatisasi visual pencahayaan yang dibangun juga menggunakan warna merah. Intensitas pencahayaan diciptakan dengan menggunakan kualitas pencahayaan low key. Penggabungan keseluruhan dari aspek tersebut untuk membuat suasana dari visual menjadi lebih hidup.

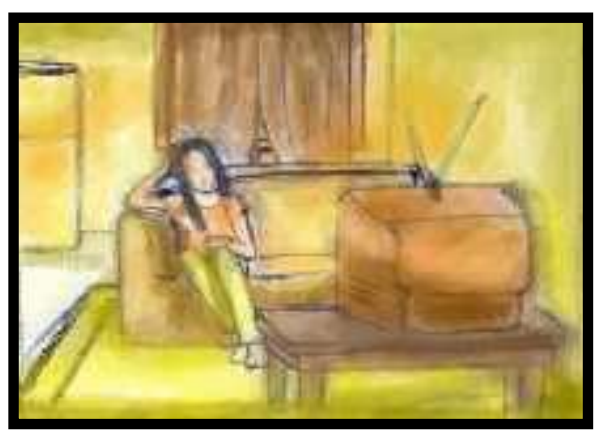

Gambar 7 :

Gambar storyboard perencanaan warna kuning dan bentuk pengambilan gambar

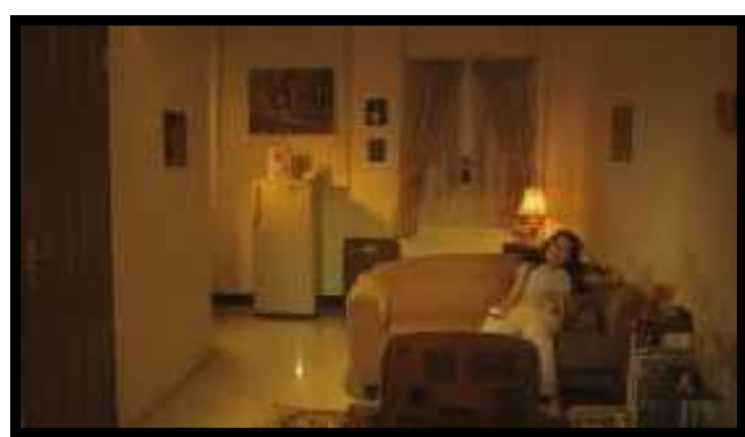

Gambar 8 :

Hasil proses penciptaan warna kuning yang disesuaikan dengan perencanaan

Warna kuning diperoleh dari kulit kelapa gading adalah warna kuning yang diciptakan sebagai simbolisasi penyampaian pesan atas pikiran yang dialami oleh tokoh dalam film televisi ini. Secara adegan tokoh dalam kondisi depresi dan dikendalikan oleh pikirannya sehingga tokoh ini harus minum obat untuk meredakan depresinya.

Penciptaan warna kuning disesusaikan dengan nuansa rumah yang memiliki properti dengan dominan warna kuning. Dekorasi artistik pada adegan ini menciptakan ruang tengah dengan penempatan properti kursi dan televisi dengan warna kuning. Untuk mendukung nuansa warna kuning juga diwujudkan melalui penggunaan kostum tokoh. Penggunaan aspek dekorasi artistik, properti dan kostum ditambahkan pencahayaan warna kuning menciptakan suasana dramatis pada visual.

Pada gambar ini menggunakan kualitas pencahayaan high key dimana gaya ini memberikan gambaran ruang yang besar. Warna kuning yang diciptakan pada gambar ini menjadikan ruang besar yang mempengaruhi pikiran dari tokoh tersebut. 


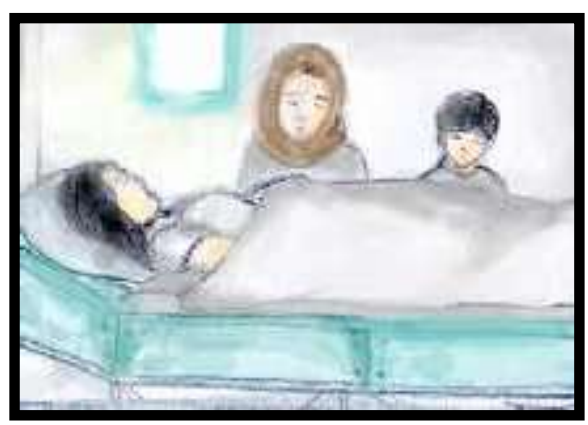

Gambar 9:

Gambar storyboard perencanaan warna putih dan bentuk pengambilan gambar

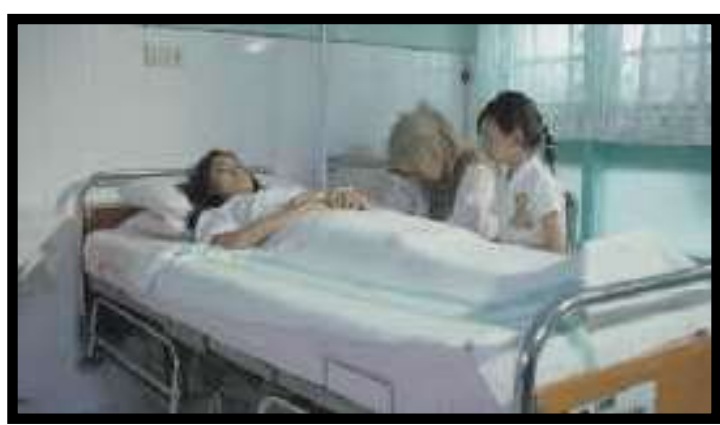

Gambar 10 :

Hasil proses penciptaan warna putih yang disesuaikan dengan perencanaan

Adegan pada gambar ini menjelaskan bagaimana warna putih mewakili pesan simbolisasi dari kesadaran tokoh. Pada gambar ini lokasi pengambilan gambar berada di kamar rumah sakit. Secara filosofi pohon kelapa gading warna putih diperoleh dari isi buah kelapa itu sendiri. Lokasi ini sangat mendukung penciptaan konsep nuansa warna putih yang ingin disampaikan melalui penggunaan properti, kostum dan pencahayaan tinggal menyesuaikan dengan lokasinya.

Warna putih dengan kualitas pencahayaan high key menyampaikan pesan dari puncak pencaritaan film televisi. Warna putih menjadi penanda kesadaran tokoh yang akan terlahir kembali setelah melewati perjuangan melawan peristiwa yang telah mengalami kehidupannya.

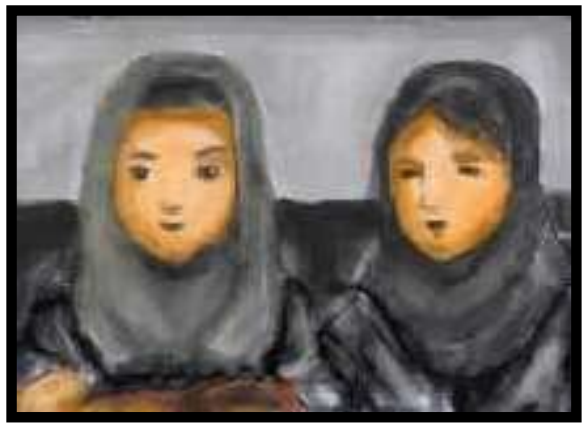

Gambar 11:

Gambar storyboard perencanaan warna hitam dan bentuk pengambilan gambar

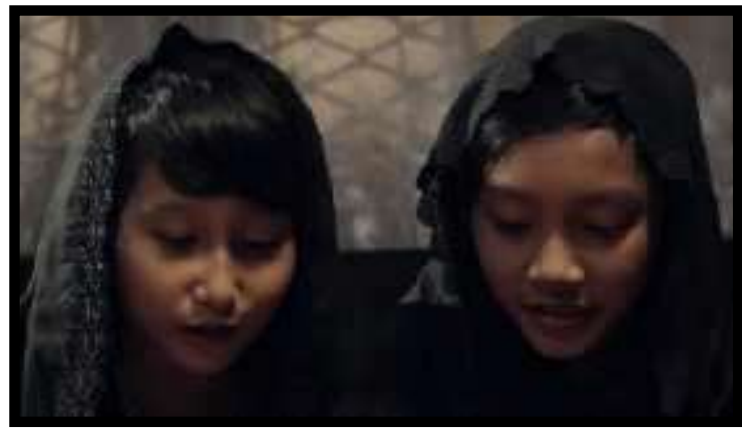

Gambar 12 :

Hasil proses penciptaan warna hitam yang disesuaikan dengan perencanaan

Warna hitam pada filosofi pohon kelapa gading diperoleh dari tanah. Unsur tanah menjadi proses awal tumbuhan hidup. Penciptaan warna hitam ingin menjelaskan secara simbolis tentang ingatan yang dialami oleh tokoh. Ingatan pada masa kecil menjadi sebuah pilihan penciptaan adegan pada film televisi ini. Warna hitam pada adegan ini diciptakan melalui kostum. Sedangakan aspek dekorasi artisitik diciptakan melalui penggunaan properti yang bernuansa warna gelap. Kualitas pencahayaan menggunakan 
low key, karena kualitas ini sangat membantu menciptakan suasana gelap pada gambar. Kekuatan dominasi warna hitam menjadikan adegan pada gambar ini memiliki tingkatan dramatisasi yang tinggi untuk menyampaikan pesan atas sebuah ingatan tokoh.

\section{Kesimpulan}

Warna merupakan sebuah ungkapan perasaan manusia yang sering kali menjadi ungkapan ekpresi dari manusia itu sendiri. Perlu sebuah pengungkapan ekpresi dari manusia melalui warna agar orang lain mengetahui apa yang dirasakan manusia tersebut. Melalui filosofi Jawa "Kakang Kawah, Adhi Ari-Ari, Getih, Puser, Kang Limo Pancer" bagaimana manusia memiliki saudara yang tidak kasat mata. Filosofi ini terdapat warna untuk menggambarkan saudara manusia yang lain.

Pohon kelapa gading menjadi simbol manusia Jawa yang tangguh dan memilik manfaat mulai dari tanah hingga daunnya. Penekanan dalam karya ini adalah bagaimana warna dapat menjadi sebuah simbol untuk menyampaikan pesan atas apa yang dirasakan Ratri dan bisa ditangkap oleh penonton. Oleh karena itu, warna menjadi sebagai peranan utama untuk menjelaskan bagaimana Ratri berjuang mengendalikan perasaan, pikiran, ingatan dan kesadarannya.

Melalui warna penonton dapat menangkap gambar yang memiliki look (nuansa) dan merasakan melalui mood (suasana) yang dibangun dari setiap adegannya.

Karya film televisi Pancer memberikan penekanan atas sebuah gambaran kehidupan manusia yang masih dikendalikan oleh nafsu. Melalui gambaran visual penoton tidak hanya menonton film televisi saja penoton juga dapat memahami dan memaknainya. Penonton akan menyadari penyampaian bahasa visual apabila warna yang diciptakan memiliki porsi yang sama untuk bisa dipahami penonton.

Karya film televisi Pancer ini menjadi bentuk tayangan alternatif kepada penonton dan menjadi harapan besar untuk memahami kebudayaan Indonesia khususnya budaya Jawa.

\section{Kepustakaan}

Berger, Arthur Asa. 2010. Pengantar Semiotika, Yogyakarta: Tiara Wacana

Block, Bruce. 2008. The Visual Story Creating The Visual Structure Of Film, TV And Digital Media, Second Edition. Oxford, UK: Focal Press.

Boggs, Joseph. M. 1992. The Art of Watching Film, dalam terjemahan Drs. Asrul Sani, Jakarta: Yayasan Citra.

Brodwell, David., dan Kristin Thompson. 2008. Film Art: An Introduction, Eight Edition. New York, America: McGraw-Hill.

Budiman, Kris. 2004. Semiotika Visual. Yogyakarta: Buku Baik.

Darmaprawira, Sulasmi. 2001. WARNA Teori dan Kreatifitas Penggunanya edisi ke-2, Bandung: Penerbit ITB.

Gandasoebrata, Soetomo. 1996. Tata Fotografi (Cinematography) edisi ke-5. Jakarta: Fakultas Film dan Televisi Jurusan Film, IKJ.

Indrajaya, Doddy Permadi. 2011. Buku Pintar Televisi Proses Pemahaman Pertelevisian Bagi Pemula. Bogor: Ghalia Indonesia. 
Ismail, H. Usmar. 1997. Kamus Kecil Istilah Film edisi ke-2. Jakarta: B.P. SDM Citra, Yayasan Pusat Perfilman.

Mascelli, Joseph V. 1986. The Five of Cinematography, terjemahan H.M.Y. Biran, Jakarta: Yayasan Citra.

Pratista, Himawan. 2008. Memahami Film. Yogyakarta: Homerian Pustaka.

Wheeler, Paul. 2001. Digital Cinematography. Oxford, MA: Focal Press.

Ward, Peter. 2000. Digital Video Camerawork. Oxford, MA: Focal Press.

http//www.seadanyadeh.blogspot.com/teknik-mewarnai-film-hitam-putih.html. 2011.

http//www.Tips otomatis Saft7.com/kualitas cahaya.2010.

http//www.bambangpriantono.multiply.com/reviews/item/262. 2011.

http//www.sacvs.wordpress.com/soundcolourvibration.com

http//www.moviesoothsayer.wordpress.com

http://kosmo.vivanews.com/news/read/132806-film_drama

http://dikiumbara.wordpress.com/category/drama-tv

http://kosmo.vivanews.com/news/read/132806-

film_drama_lebih_efektif_ketimbang_berita 